Supplement of Clim. Past, 13, 201-216, 2017

http://www.clim-past.net/13/201/2017/

doi:10.5194/cp-13-201-2017-supplement

(C) Author(s) 2017. CC Attribution 3.0 License.

(c) (i)

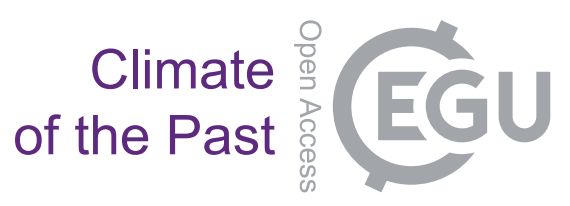

Supplement of

\title{
Changes in Holocene meridional circulation and poleward Atlantic flow: the Bay of Biscay as a nodal point
}

Yannick Mary et al.

Correspondence to: Yannick Mary (pelagos@ @otmail.fr) and Frédérique Eynaud (frederique.eynaud@u-bordeaux.fr)

The copyright of individual parts of the supplement might differ from the CC-BY 3.0 licence. 
Planktonic foraminifera assemblages from core PP10-07 (unpublished) were determined after counts (minimum of 300 specimens) in the $>150 \mu \mathrm{m}$ fraction. Species identification follows Hemleben et al. (1989) and Kennett and Srinivasan (1983). Foraminiferal assemblages are here described by the relative percentages of each species, calculated relative to the total sum of planktonic foraminifera (Figure S1).

$\begin{array}{ll}\text { ORBU } & \text { O. universa } \\ \text { CONG } & \text { G. conglobatus } \\ \text { RUBR } & \text { G. ruber rosea } \\ \text { RUBA } & \text { G. ruber alba } \\ \text { TENE } & \text { G. tenellus } \\ \text { SACC } & \text { G. sacculiferus } \\ \text { DEHI } & \text { S. dehiscens } \\ \text { ADAM } & \text { H. adamsi } \\ \text { HAST } & \text { H. aequilateralis } \\ \text { CALI } & \text { G. calida } \\ \text { BULL } & \text { G. bulloides } \\ \text { FALC } & \text { G. falconensis } \\ \text { DIGI } & \text { G. digitata } \\ \text { RUBS } & \text { G. rubescens } \\ \text { HUMI } & \text { T. humilis } \\ \text { QUIN } & \text { G. quinquloba } \\ \text { PCHS } & \text { N. pachyderma senestre } \\ \text { PCHD } & \text { N. pachyderma dextre } \\ \text { DUTE } & \text { N. dutertrei } \\ \text { HEXA } & \text { T. hexagona } \\ \text { PULL } & \text { P. obliquiloculata } \\ \text { INFL } & \text { G. inflata } \\ \text { TRUS } & \text { G. truncatulinoides senestre } \\ \text { TRUD } & \text { G. truncatulinoides dextre } \\ \text { CRAS } & \text { G. crassaformis } \\ \text { HIRS } & \text { G. hirsuta } \\ \text { SCIT } & \text { G. scitula } \\ \text { MENA } & \text { G. menardii } \\ \text { TUMI } & \text { G. tumida } \\ \text { NITI } & \text { C. nitida } \\ \text { GLUT } & \text { G. glutinata } \\ \text { THEY } & \text { G. theyeri } \\ \text { UVUL } & \text { G. uvula } \\ \text { OTHER (not determined) } \\ & \end{array}$

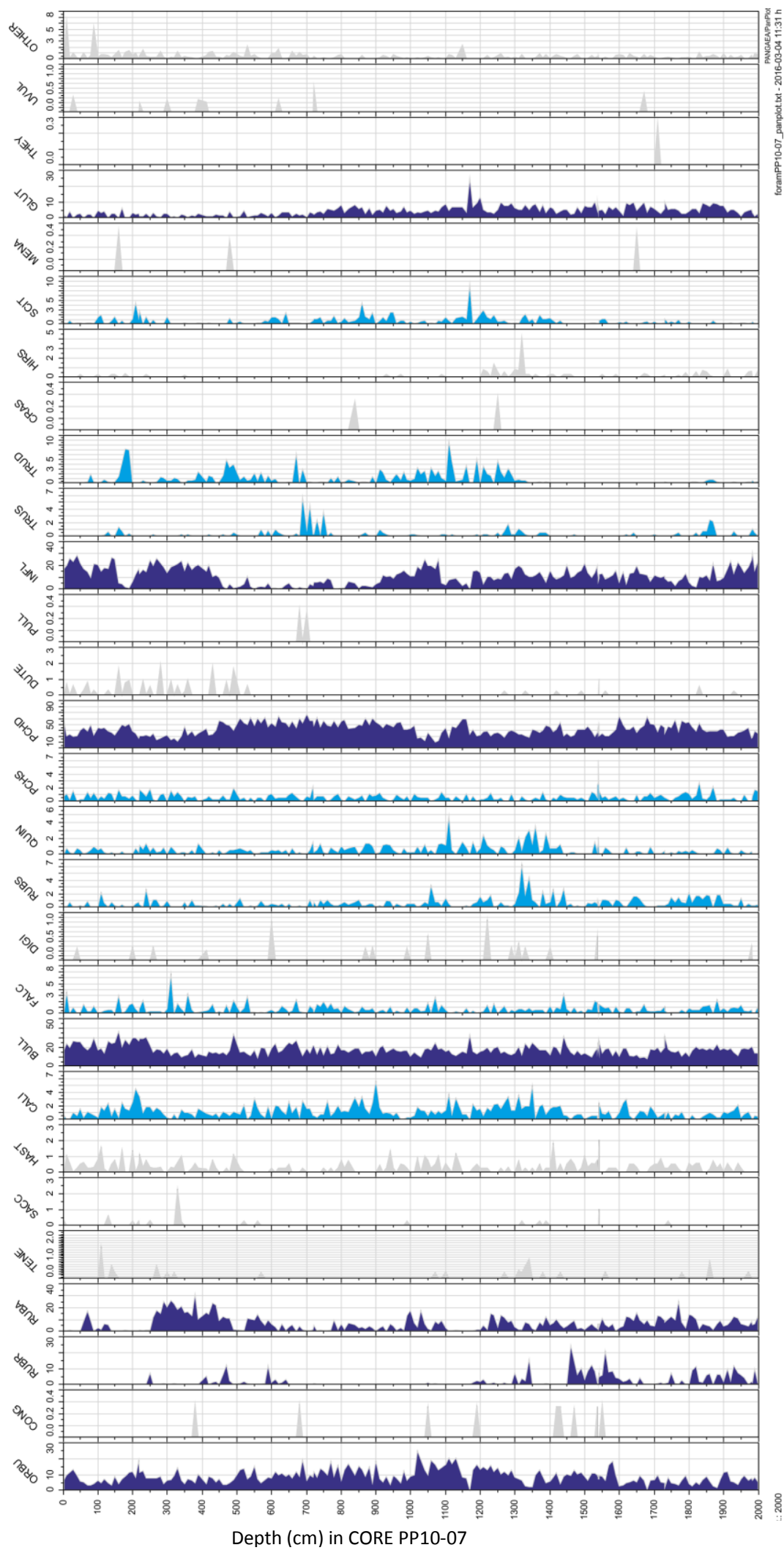

Figure S1: Planktonic foraminifera assemblages (relative abundances- \%) in core PP10-07. Color code: Dark blue: characteristic species/ light blue: minor species/ grey: fortuitous species. 
27 Relative abundance data obtained after the analysis of planktonic foraminifera assemblages (as published in 28 Mojtahid et al., 2013 for core Ks10B, and from unpublished counts for core PP10-07, see above Figure S1) were used 29 for MAT calculations (see Methods of the paper) according to the following root mean square errors of prediction 30 (Table S3). Seasonal mean calculations are displayed on Figure S2 for core KS10b and Figure S3 for core PP10-07.

31 These plots underline the good coherency with modern sea-surface conditions except during warm spells as discussed in the core manuscript. They also show that fall and spring seasons mirror the mean annual values in 33 absolute values.

\begin{tabular}{|c|c|c|c|c|c|}
\hline $\begin{array}{c}\text { Hydrographical } \\
\text { parameters }\end{array}$ & $\begin{array}{c}\text { Mean } \\
\text { Annual SST } \\
\left({ }^{\circ} \mathrm{C}\right)\end{array}$ & $\begin{array}{c}\text { Mean Winter } \\
\text { (January-February } \\
\text {-March) -JFM } \\
\text { SST }\left({ }^{\circ} \mathrm{C}\right)\end{array}$ & $\begin{array}{l}\text { Mean Spring } \\
\text { (April May-June) } \\
\text {-AMJ SST }\left({ }^{\circ} \mathrm{C} \text { ) }\right.\end{array}$ & $\begin{array}{l}\text { Mean Summer } \\
\text { (July- August- } \\
\text { September) -JAS } \\
\text { SST }\left({ }^{\circ} \mathrm{C} \text { ) }\right.\end{array}$ & $\begin{array}{c}\text { Mean Fall } \\
\text { (October -November } \\
\text {-December) - OND } \\
\text { SST }\left({ }^{\circ} \mathrm{C}\right)\end{array}$ \\
\hline RMSEP & 1.1 & 1.2 & 1.1 & 1.3 & 1.2 \\
\hline
\end{tabular}

Table S1: Prediction error (RMSEP : root mean square error of prediction) of the MAT technique developed at EPOC (MATR_1007PF, e.g. Eynaud et al., 2013). 

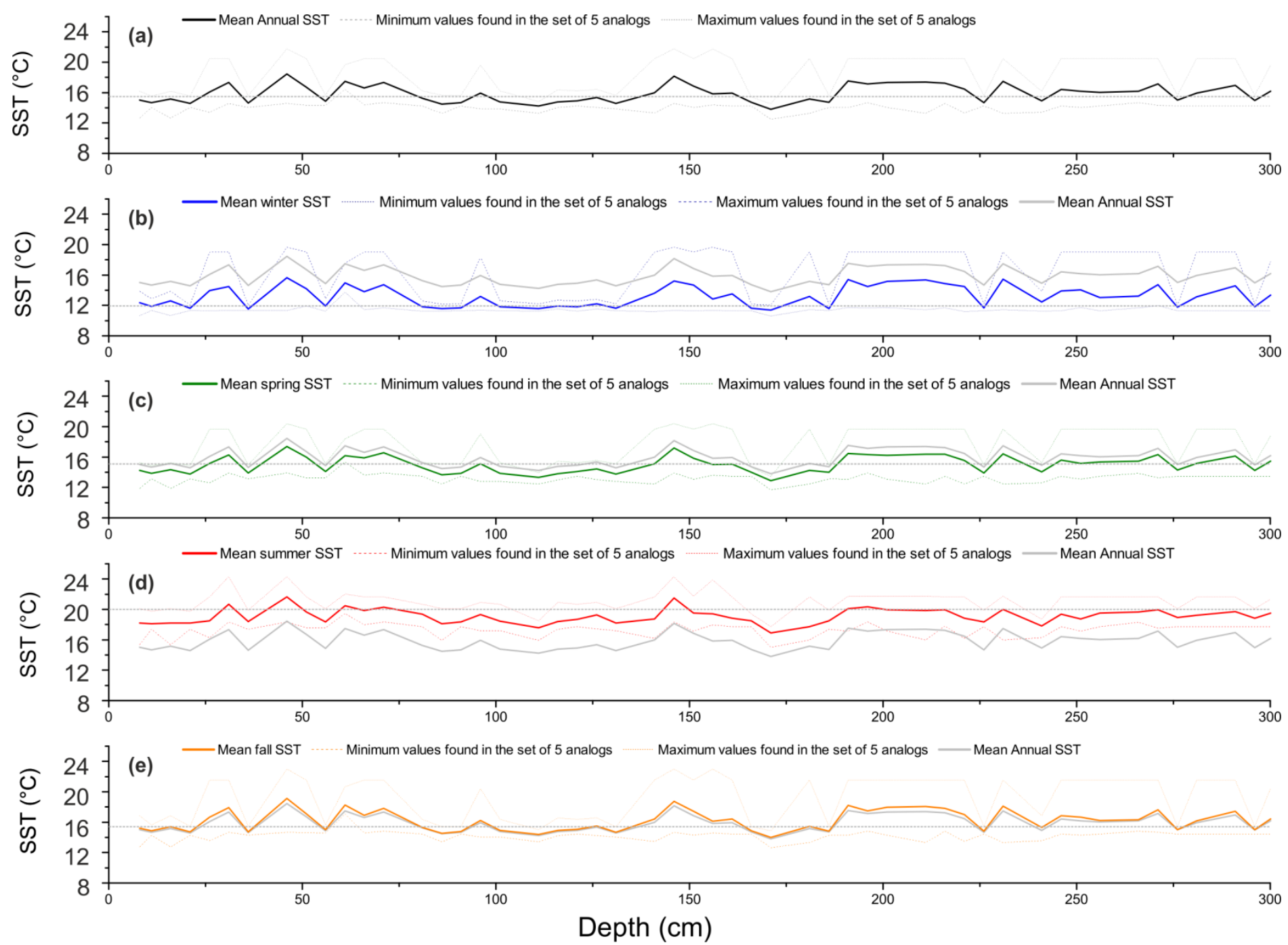

Figure S2: SST quantifications after MATR_1007PF on core Ks10b, with from the top to the bottom: (a) mean annual SST, (b) mean winter (JFM), (c) mean spring (AMJ), (d) mean summer (JAS), (e) mean fall (OND) SST. The seasonal means are compared to the annual one (grey curve). On each graph, colored dotted lines identify the respective minimal and maximal SST values found in the set of the 5 selected analogs. The horizontal grey dotted lines correspond to the modern values for each season after Schäfer-Neth and Manschke, 2002 -WOA sample tool. Available at: http://www.geo.uni-bremen.de/geomod/staff/csn/ woasample.html 

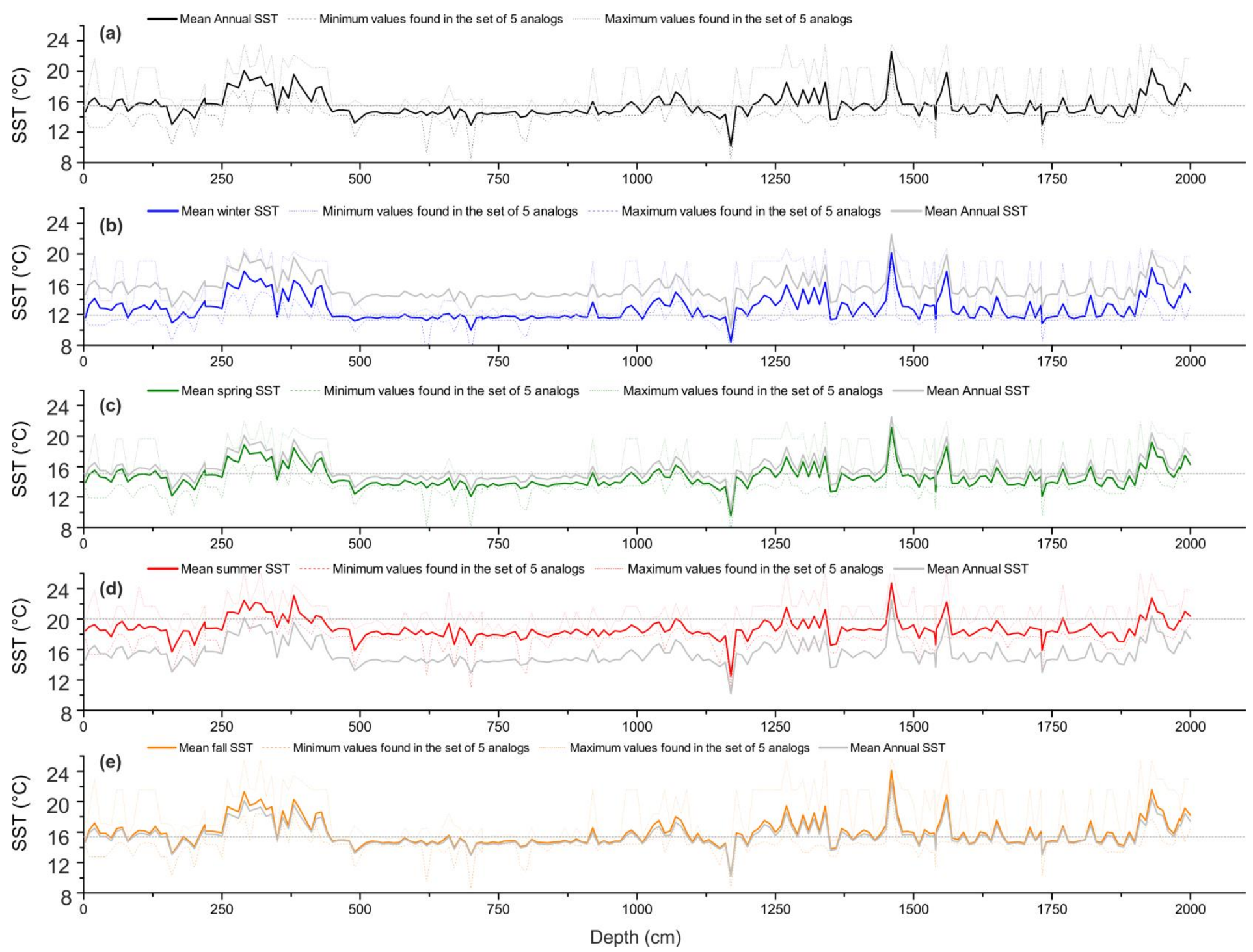

Figure S3: SST quantifications after MATR_1007PF on core PP10-07, with from the top to the bottom: (a) mean annual SST, (b) mean winter (JFM), (c) mean spring (AMJ), (d) mean summer (JAS), (e) mean fall (OND) SST. The seasonal means are compared to the annual one (grey curve). On each graph, colored dotted lines identify the respective minimal and maximal SST values found in the set of the 5 selected analogs. The horizontal grey dotted lines correspond to the modern values for each season after Schäfer-Neth and Manschke, 2002 -WOA sample tool. Available at: http://www.geo.uni-bremen.de/geomod/staff/csn/ woasample.html 

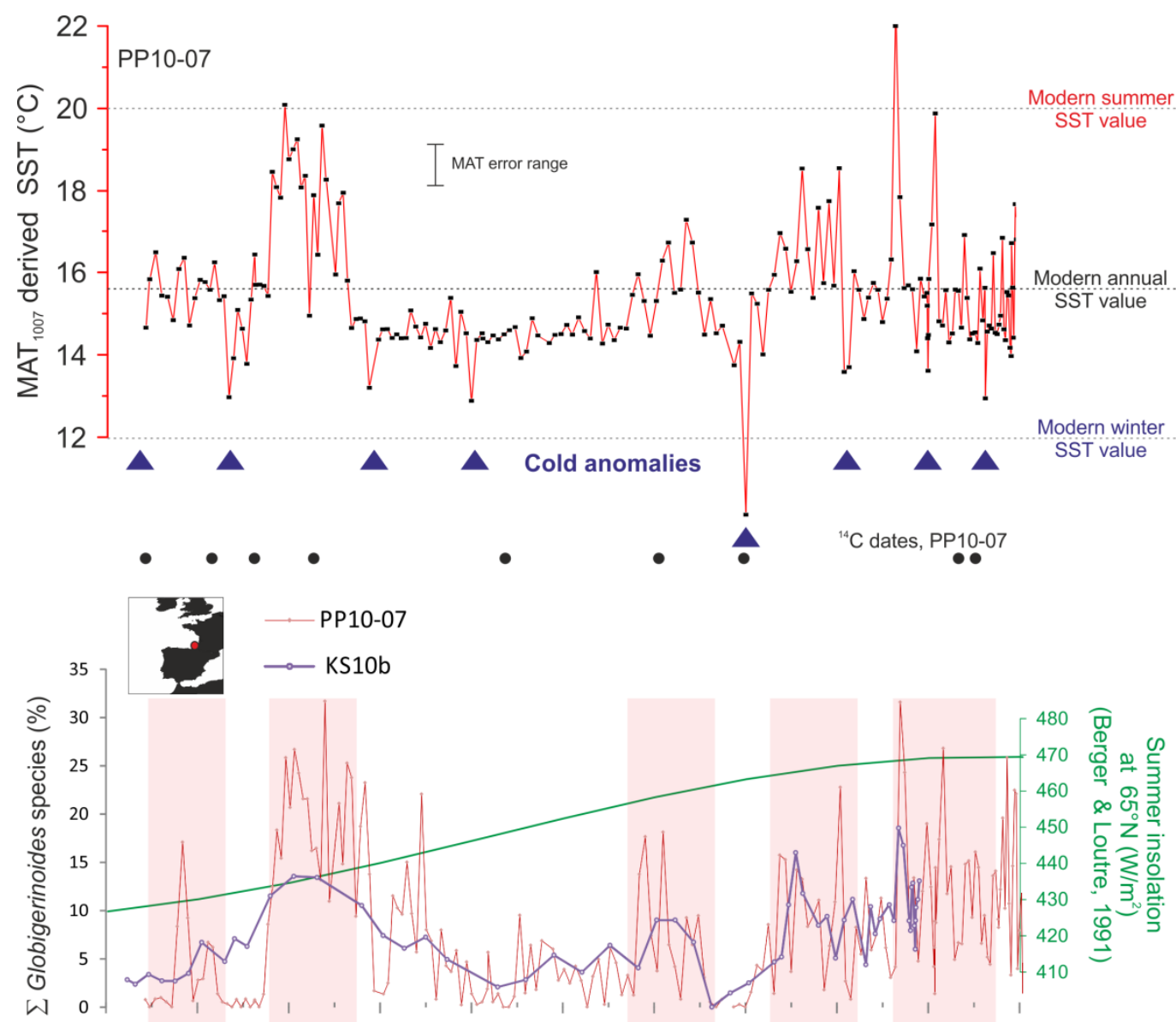

Age Cal BP (Year) 


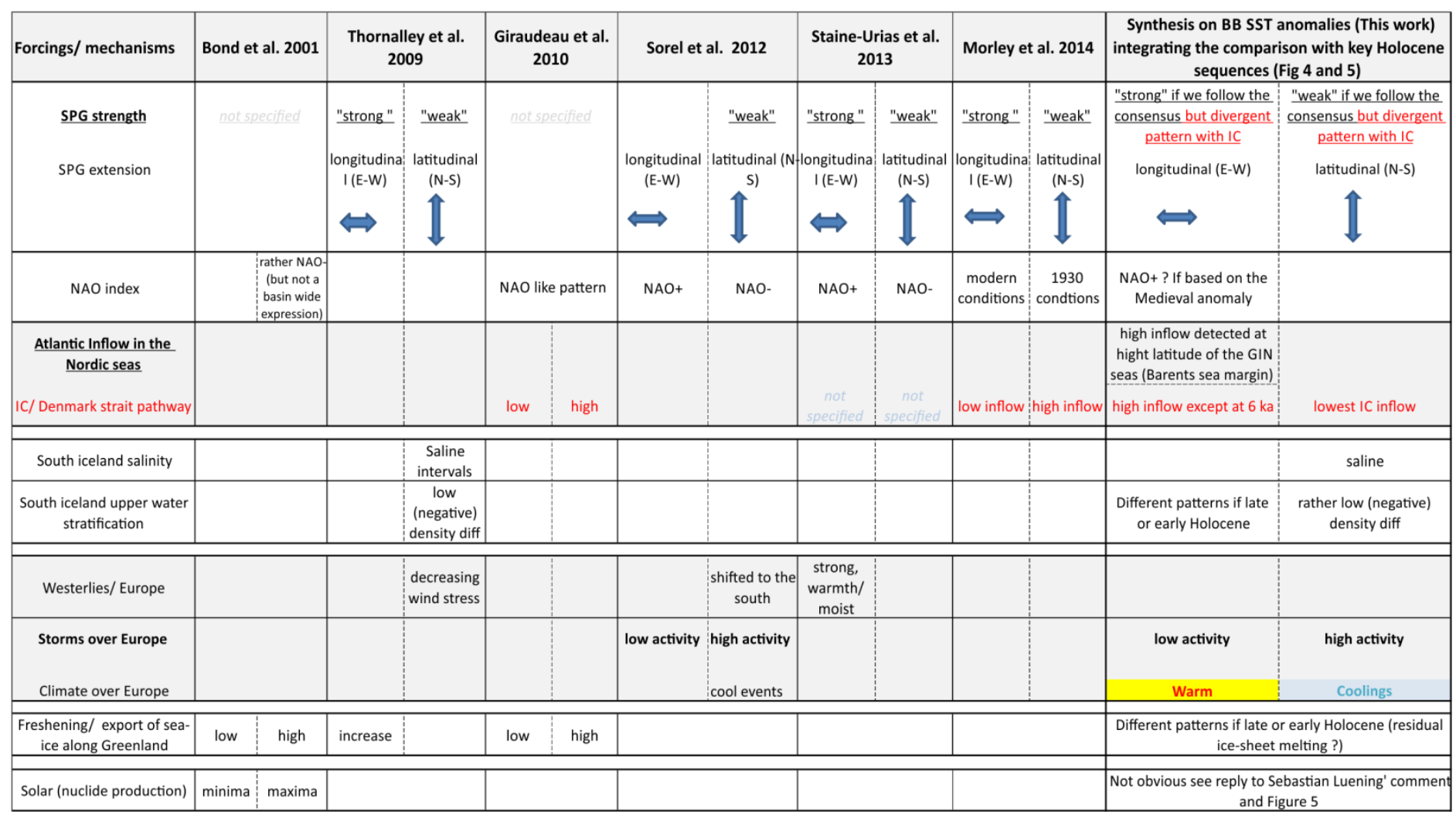

Table S2: Compilation of relevant paleo-observation done with various bibliographic sources since the Bond et al. (2001) paper. The two last columns gather observations in the Bay of Biscay (BB) with those provided in the selected bibliography. 